Arch. Histol. Cytol., Vol. 61, No. 1 (1998)

p. $75-81$

\title{
Corticosteroids Stimulate the Differentiation of Growth Hormone Cells But Suppress That of Prolactin Cells in the Fetal Rat Pituitary
}

\author{
Kazuhisa SATo and Yuichi G. WatanaBE \\ Department of Biology, Faculty of Science, Niigata University, Niigata, Japan
}

Received November 27, 1997

\begin{abstract}
Summary. An organ culture study was carried out to examine the effects of adrenal corticosteroids on the development of growth hormone (GH) cells and prolactin (PRL) cells. The adenohypophysial primordia were separated from 13.5-day-old fetal rats and maintained in vitro for 8 days with or without cortisol. Immunohistochemical examination of these explants showed that cortisol stimulated the differentiation of GH cells but suppressed that of PRL cells in a dosedependent manner. In the absence of cortisol there were more PRL cells. Corticosterone had a similar effect on the developing adenohypophysis. When the pituitary primordia of Day 16.5 were cultured for 5 days and studied by the in situ hybridization technique, the expression of GH and PRL mRNA was found to be parallel with the immunoreactivity of the respective hormones. These data are discussed in relation to the normal development of GH and PRL cells in the fetal rat adenohypophysis.
\end{abstract}

The question of how different types of hormoneproducing cells develop in the fetal pituitary has not been answered completely. Organ culture studies of undifferentiated adenohypophysial primordia of the rat have showen that, except for GH cells, hormone producing cells arise without inductive influence from other tissues (NEMESKÉRI and HALÁSZ, 1989). The question of what factor is involved in the differentiation of GH cells was answered by HEMMING et al. (1984, 1988), who demonstrated an indispensable role of cortisol in the development of $\mathrm{GH}$ cells. NoGAMI et al. (1995) confirmed this stimulative effect of glucocorticoids on differentiating GH cells.

At present, evidence suggests that there exists a close developmental relationship between GH and PRL cells. BEHRINGER et al. (1988) and BORRELLI et al.
(1989) found a marked decrease in the number of PRL cells in transgenic mice where GH cells were ablated by a genetic means. This fact led these investigators to suggest that GH and PRL cells are derived from a common precursor. SimMONS et al. (1990) showed that both GH and PRL cells possess a protein referred to as Pit-1, which is known to activate GH and PRL promoters. It therefore seems of interest to investigate whether developing GH and PRL cells behave similarly in response to glucocorticoid treatment. The administration of corticosteroids was reported to have a suppressive effect on PRL gene expression in the adult rat pituitary (ADLER et al., 1988), but to date the effect of corticosteroids on developing PRL cells has received no attention. In view of these findings, an in vitro experiment was undertaken where the pituitary primordia of fetal rats were cultured in the presence of adrenocortical steroids.

This paper demonstrates that glucocorticoids have suppressive influences on differentiating PRL cells in contrast to the stimulative role of these steroids in the development of GH cells.

\section{MATERIALS AND METHODS}

\section{Animals and organ culture}

Adult rats of the Sprague-Dawley strain were mated at night. If spermatozoa were found in vaginal smears the next morning, that day was designated as Day 0.5 of gestation. Pregnant rats at Days 13.5 and 16.5 of gestation were anesthetized with ketamine hydrochloride and fetuses were removed for microsurgery. In this study, pituitary primordia were cultured with the surrounding brain and mesenchymal 
tissues. The organ culture was performed as described previously (WATANABE, 1987). The primordia explanted on Day 13.5 were kept for 8 days. In view of the data that cortisol is the main adrenal steroid in the rat fetus (KALAVSKY, 1971), we first tested the effect of cortisol and then that of corticosterone. Both steroids were purchased from Sigma (MO, USA) and added to the medium at concentrations of 50,275 and $500 \mathrm{nM}$. Corticosterone was first solved in ethanol and diluted to the final concentrations with distilled water. For controls, vehicles were added. At the end of the culture period, explants were fixed in Bouin's solution. After removing cellulose acetate membranes in ethanol, they were embedded in paraffin and cut at $2 \mu \mathrm{m}$ for immunohistochemistry. For in situ hybridization, the pituitary primordia were separated on Day 16.5 because the primordia explanted on Day 13.5 were too small to be processed for frozen sectioning. These cultures were maintained for 5 days.

\section{Immunohistochemistry}

After deparaffinization, sections were immunohistochemically stained according to the PAP method by the use of anti-rat GH (HAC-RT25-01-RBP85) and anti-rat PRL (HAC-RT26-01-RBP85) which were kindly supplied by Dr. K. WAKABAYASHI (Gunma University, Japan). For cell counting, every 7 th section was mounted on the same slide, and immunostained for both the antisera. The number of immunoreactive cells on each slide was counted.

\section{In situ hybridization}

Culture explants were fixed in $4 \%$ paraformaldehyde in $0.1 \mathrm{M}$ phosphate buffer for $24 \mathrm{~h}$ at $4^{\circ} \mathrm{C}$. The fixed explants were immersed in $30 \%$ sucrose in PBS at $4^{\circ} \mathrm{C}$ overnight, embedded in OCT, and stored at $-80^{\circ} \mathrm{C}$. Cryostat sections were cut at $5 \mu \mathrm{m}$ and mounted on APS-coated slides (Matsunami, Japan).

Rat GH cDNA was kindly supplied by Dr. J. D. BAXTER (University of California, San Francisco, CA), and rat PRL cDNA was a gift from Dr. A MAUER (University of Iowa, IA). All reagents used for in situ hybridization were purchased from Boehringer Mannheim, Germany. In vitro transcription was performed with the DIG RNA labeling kit according to the manufacturer's protocol. Digoxigenin-labelled RNA probes were precipitated with ethanol and dissolved in $50 \mathrm{ml}$ of dimethyl-dicarbonate-treated water. The probes were diluted $(1: 100)$ with a hybridization solution consisting of $2 \%$ of a blocking reagent, $5 \times \mathrm{SSC}, 50 \%$ formamide, and then denatured for $2 \mathrm{~min}$ at $90^{\circ} \mathrm{C}$ and chilled in ice. The slides were incubated with a hybridization solution containing denatured RNA probes at $45^{\circ} \mathrm{C}$ for $16 \mathrm{~h}$. After three washes with buffer A ( $100 \mathrm{mM}$ Tris- $\mathrm{HCl}$, $\mathrm{pH} 7.5,150 \mathrm{mM} \mathrm{NaCl}$ ), the sections were treated with a $0.5 \%$ blocking reagent in buffer $\mathrm{A}$ for $30 \mathrm{~min}$ at room temperature followed by incubation with antidigoxigenin-AP, Fab fragments (1:500) in buffer A for $1 \mathrm{~h}$. The sections were then washed in buffer A three times and then in buffer B $(100 \mathrm{mM}$ Tris- $\mathrm{HCl}$, $\mathrm{pH} 9.5,100 \mathrm{mM} \mathrm{NaCl}, 50 \mathrm{mM} \mathrm{MgCl}_{2}$ ). Finally, the sections were incubated with 4-nitro blue tetrazolium chloride $(33.5 \mu \mathrm{g} / \mathrm{ml})$ and 5-bromo-4-chloro-3-indolylphosphate $(165 \mu \mathrm{g} / \mathrm{ml})$ in buffer B at room temperature in darkness.

\section{RESULTS}

\section{Effect of cortisol on the number of immunoreactive GH and PRL cells}

When the pituitary primordia of 13.5-day-old rat fetuses were removed and cultured for 8 days without cortisol, no GH cells were observed (Fig. 1a). In the presence of cortisol, on the other hand, all culture explants were found to contain GH cells (Fig. 1b-d). In cortisol-treated explants, GH cells first appeared on the 4th day of culture. The numbers of immunoreactive cells increased through the duration of the organ culture. Figure 2 summarizes the results of cell counting. The numbers of GH cells increased in parallel with the cortisol concentations.

Unlike GH cells, PRL cells were most frequently found when the pituitary primordia were cultured without cortisol (Fig. 1e). Thus, at a concentration of $500 \mathrm{nM}$ cortisol, only a few or no PRL cells were observed (Figs. 1h, 2).

When cortisol was replaced with corticosterone, almost identical results were obtained (data not shown).

\section{Effect of cortisol on GH and PRL mRNA expression}

As already described, the pituitary primordia for in situ hybridization were separated on Day 16.5 of fetal age and cultured with or without cortisol $(275 \mathrm{nM})$ for 5 days. As expected, GH and PRL transcripts were found only when culture explants possessed immunoreactive cells in both cases. Thus no GH transcripts were observed in those explants kept without cortisol (Fig. 3a). In the presence of cortisol many cells were found to express GH transcripts (Fig. 3b). Conversely, PRL transcripts were abundantly detected in the absence of cortisol (Fig. 3c), whereas little PRL mRNA was present when explants were maintained with cortisol (Fig. 3d). 
a
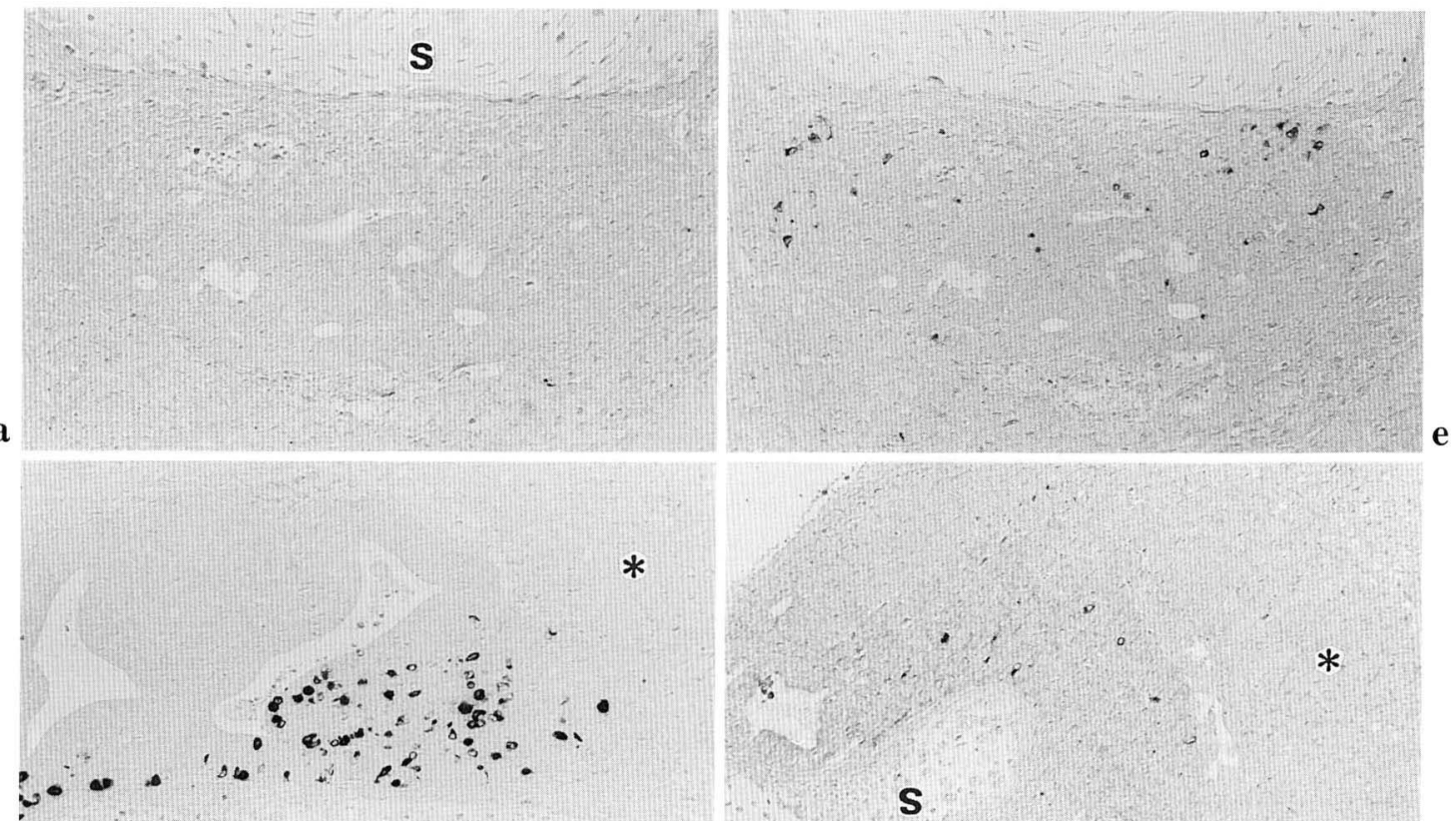

b

S
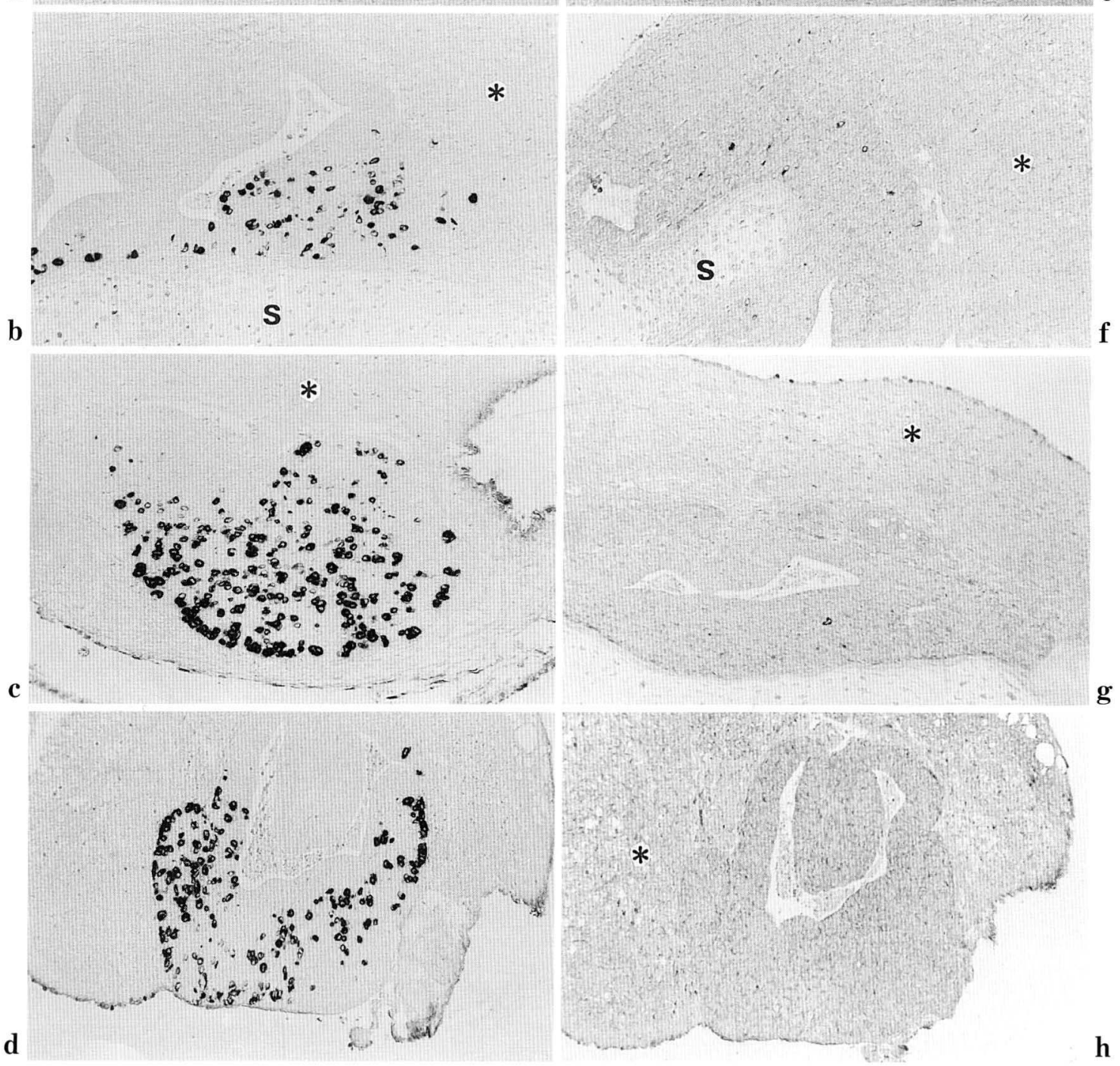

Fig. 1. Portions of fetal rat pituitary explanted on Day 13.5 and grown in $\alpha$ MEM containing $0 \mathrm{nM}$ (a and e), $50 \mathrm{nM}$ (b and $\mathbf{f}$ ), $275 \mathrm{nM}$ ( $\mathbf{c}$ and $\mathbf{g}$ ) and $500 \mathrm{nM}$ (d and $\mathbf{h}$ ) of cortisol for 8 days. Co-cultured brain (asterisk) and sphenoid cartilage (s) are also seen. Sections immunohistochemically stained for GH (a-d) and PRL $(\mathbf{e}-\mathbf{h}) . \times 115$ 
a

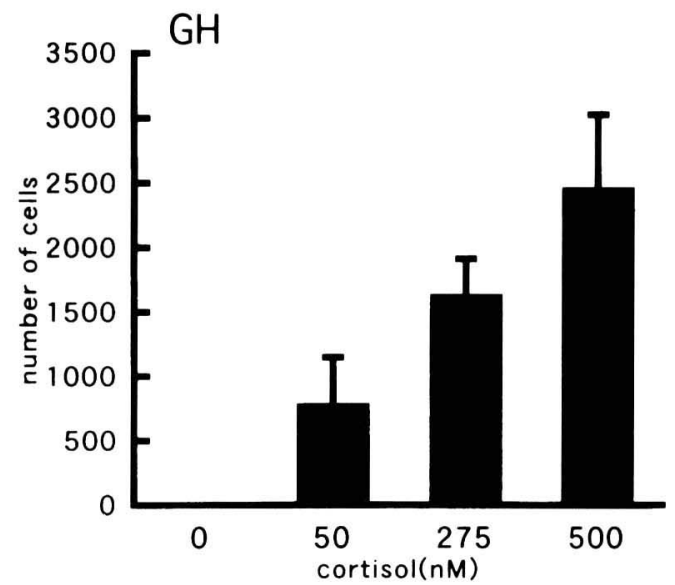

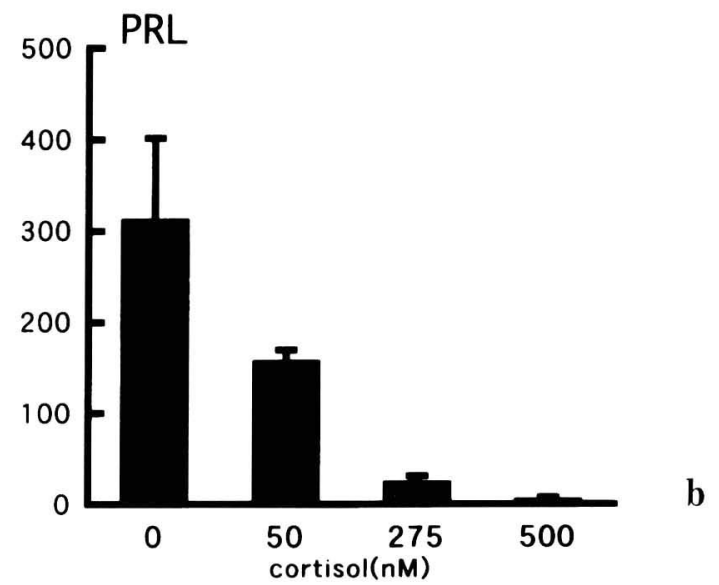

Fig. 2. The numbers of immunoreactive GH (a) and PRL (b) cells contained in the fetal rat pituitary primordia explanted on Day 13.5 and kept with varying doses of cortisol for 8 days. Note dose-dependent stimulative and suppressive effects of cortisol on developing GH and PRL cells, respectively.

a
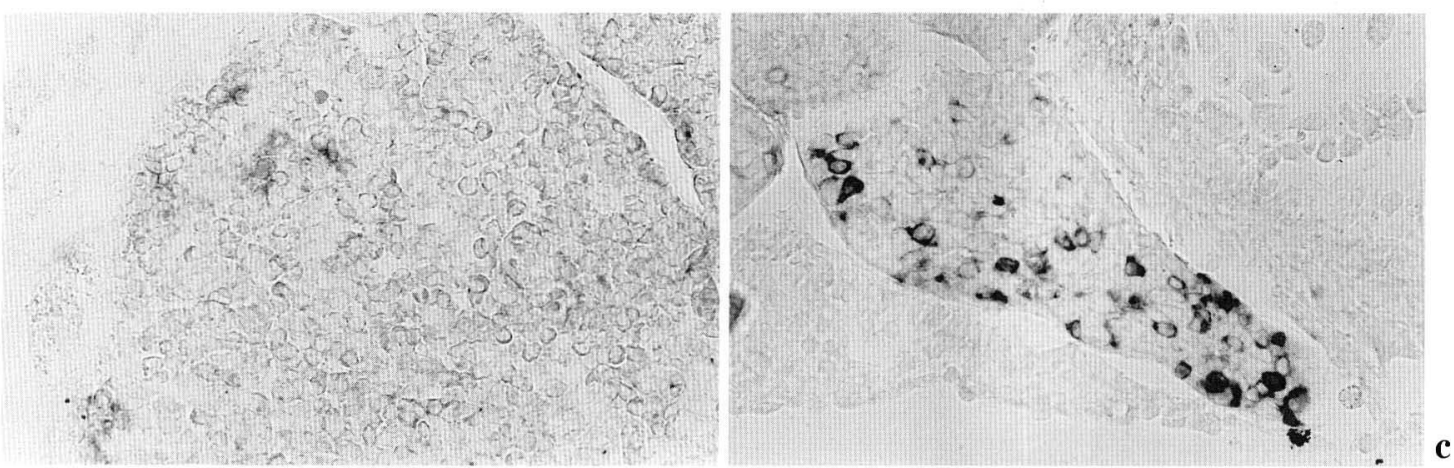

b
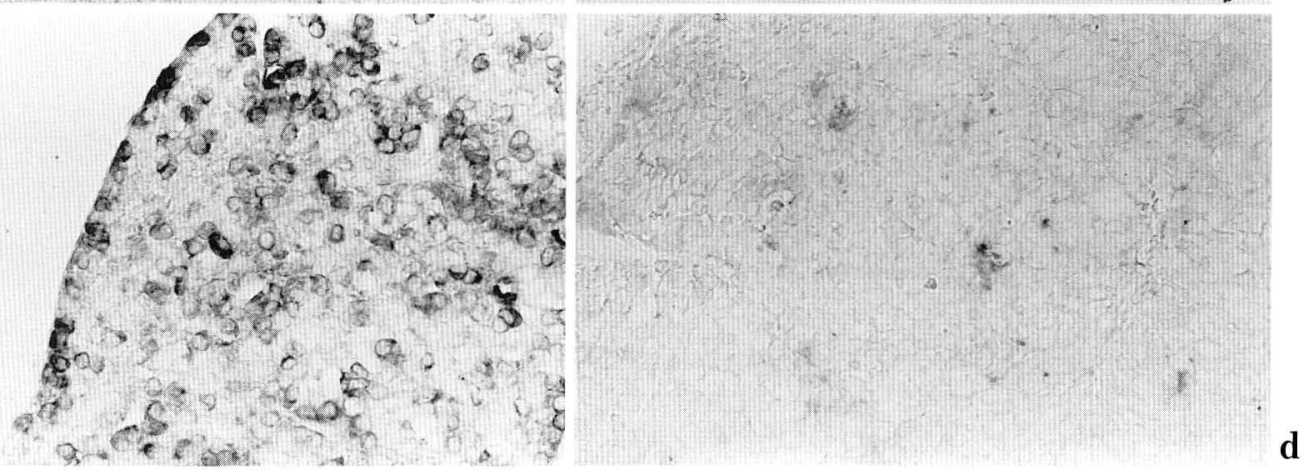

Fig. 3. Frozen sections of fetal rat pituitary explanted on Day 16.5 and grown in $\alpha$ MEM with $0 \mathrm{nM}$ (a, c) and $275 \mathrm{nM}(\mathbf{b}, \mathbf{d})$ of cortisol. Sections were processed for in situ hybridization with digoxigeninlabeled GH cDNA (a, b) or PRL cDNA (c, d). $\times 230$ 


\section{DISCUSSION}

Adenohypophysial hormone-producing cells do not differentiate at the same time during development. In fetal rats, the ACTH cell is the first cell type known to appear as early as Day 15 of gestation (DUPOUY and Dubois, 1975; SÉTÁló and NAKANE, 1976; WATANABE and DAIKOKU, 1979; DupouY, 1980; Chatelain and Cheong, 1986; Nemeskéri et al., 1988). During the subsequent 2-3 days, the TSH cells and gonadotropes come to be immunohistochemically detectable. Finally, on Days 18-19, GH and PRL cells appear almost simultaneously (NOGAMI et al., 1989; WATANABE and HARAGUCHI, 1994). The interpretation of such sequential differentiations of various cell types was previously difficult. We can, however, now propose an explanation as to why GH cells differentiate considerably later than ACTH cells. In the first place, it should be emphasized that the fetal adenohypophysis is indispensable for the development of the fetal adrenal gland (KITCHELL, 1950; KitChell and Wells, 1952; Cohen, 1960; Jost, 1966; KALAVSKY, 1971). Soon after their differentiation in the fetal hypophysis, ACTH cells undergo rapid proliferation (WATANABE and DAIKOKU, 1979). Evidence indicates that plasma ACTH can be detected by radioimmunoassay in 17-day-old rat fetuses, with a peak on Day 19 (Chathelain and Cheong, 1986). Such an elevated level of ACTH is responsible for the release of corticosteroids, which have actually been detected in the serum of fetal rats from Day 17 (CoHEn, 1973) or Day 18 (KALAVSKY, 1971). It must be emphasized that maternal adrenalectomy has little influence upon the serum corticosterone concentration of fetuses (DuPOUY et al., 1975). Under the influence of circulating corticosteroids mostly of fetal origin, the differentiation of $\mathrm{GH}$ cells takes place as demonstrated in the present study and in other in vivo (NogAMI et al., 1989) and in vitro experiments (Hemming et al., 1984). Thus the synthesis and release of ACTH from the fetal pituitary must occcur before the differentiation of $\mathrm{GH}$ cells takes place.

Although corticosterone is known to be the major corticosteroid in rats as in other rodents, there is a notable difference between the adult and fetus. KALAVSKY (1971) showed that the adrenal cortex of 18-day-old fetal rats contained far greater amounts of cortisol than of corticosterone. This finding is supported by the in situ hybridization study by KEENEY et al. (1995), who have demonstrated that the adrenal cortex of the fetal mouse transiently expresses mRNA of $17 \alpha$-hydroxylase cytochrome P450 that is required for the production of cortisol. Our study showed that both cortisol and corticosterone were found to induce the differentiation of GH cells. Cortisol, however, is more likely involved in the acutal cytogenetical process of $\mathrm{GH}$ cells in view of the production of this steroid in correspondence with the stage (Day 18) when GH cells differentiate in the fetal rat pituitary.

In the present study, the differentiation of PRL cells was suppressed in the presence of corticosteroids. As already described, blood levels of glucocorticoids in fetal rats are high at Day 18 when the first GH and PRL cells appear in the pituitary. This fact well explains why the number of PRL cells remains very low while GH cells undergo a marked increase in number between Days 18 and 21 (WATANABE and HARAGUCHI, 1994). A quantitative Western blot analysis performed by NAGATA et al. (1992) showed that the pituitary content of PRL increases only slightly from Days 19 to 21, being twofold versus tenfold for that of GH. According to the present data, the number of immunoreactive PRL cells was greatest in the absence of glucocorticoids. Thus the differentiation of PRL cells may be a 'default' pathway in the fetal adenohypophysis. Why the development of GH cells has priority over that of PRL under the influence of circulating glucocorticoids remains to be determined.

Evidence presently available indicates that a pituitary specific transcription factor called Pit-1 (GHF-1) is involved in the differentiation of both GH and PRL cells. Although no effort was made to detect this transcription factor in the present study, glucocorticoid probably suppressed Pit-1 expression, at least in PRL cells. This postulation comes from the observation that Pit-1 expression in PRL cells is inhibited by glucocorticoids (SUBRAMANIAM et al., 1997). As for GH cells, on the other hand, NoGAMI et al. (1997) have provided data suggesting that the induction of $\mathrm{GH}$ mRNA by glucocorticoids in the fetal pituitary is not through a direct effect by these steroids, but rather is mediated by a newly synthesized protein. Further studies are needed for ditermining the effect of corticosteroids on $\mathrm{GH}$ expression in the developing rat pituitary.

On the basis of experiments in which GH-expressing cells were genetically deleted, most investigators are inclined to think that not only GH cells but also PRL cells are derived from a common GH-producing stem cell. In the present study, culture explants contained only PRL cells in the absence of corticosteroids. This raises the question as to whether these PRL cells once produced GH during an early stage of the culture period. We could not detect any GH cells by immunohistochemistry, at least in the explants 
that were removed at Day 13.5 and maintained for 58 days in culture (data not shown). However, in considering the small amounts of pituitary hormonesparticularly in the initial phase of development, further cytological studies are necessary for determining how PRL cells differentiate in the absence of corticosteroids.

Recent immunocytochemical investigations have shown the presence of bihormonal cells containing both GH and PRL at the same time in the adenohypophysis of rats (BOOCKFOR et al., 1986; NikitovitchWinter et al., 1987; PORTER et al., 1990, 1991; NoGAMI et al., 1995), cows (HASHIMOTO et al., 1985) and mice (SASAKI and IWAMA, 1989). The occurrence of such bihormonal cells, or somatomammotropes, also suggests that there exists a close developmental relationship between GH and PRL cells. However, according to out previous immunohistochemical data on the fetal pituitary (WATANABE and HARAGUCHI, 1994), the development GH and PRL cells may be independent. We observed that the GH cells differentiate predominantly in the posterior half of the fetal rat pituitary gland, whereas PRL cells arise in its anterior part. This finding suggests the possibility that the segregation of precursors of GH and PRL cells already occurs at an early stage of development. If this is the case, it is conceivable that the glucocorticoids influence each of the two types of precursor cells separately. Further work is needed to clarify the relationship between developing GH and PRL cells during fetal life.

Acknowledgements. We are deeply indebted to Dr. M. FingERMAN (Tulane University) for his critical reading of the manuscript.

\section{REFERENCES}

Adler, S., M. L. Waterman, X. He and M. G. RosenFELD: Steroid receptor-mediated inhibition of rat prolactin gene expression does not require the receptor DNA-binding domain. Cell 52: 685-695 (1988).

Behringer, R. R., L. S. Mathews, R. D. Palmiter and R. L. BRINSTER: Dwarf mice produced by genetic ablation of growth hormone-expressing cells. Genes Devel. 2: 453-461 (1988).

Boockfor, F. R., J. P. Hoeffler and L. S. Frawley: Estradiol induces a shift in cultured cells that release prolactin or growth hormone. Amer. J. Physiol. 250: E103-105 (1986).

Borrelli, E., R. A. Heyman, C. Arias, P. E. Sawchenko and R. M. Evans: Transgenic mice with inducible dwarfism. Nature 339: 538-541 (1989).

Chatelain, A. and H. S. Cheong: Immunoreactive forms of ACTH released by the adenohypophysis of the rat during the perinatal period. In vivo and in vitro studies. J. Physiol. (Paris) 81: 361-367 (1986).

Chatelain, A., J. P. Dupouy and M. P. Dubois: Ontogenesis of cells producing polypeptide hormones (ACTH, MSH, LPH, GH, prolactin) in the fetal hypophysis of the rat: influence of the hypothalamus. Cell Tiss. Res. 196: 409-427 (1979).

Cohen, A.: Poids des surrenales du foetus de rat decapité injecté d'hydrocortisone ou de corticostimuline à divers stades du développement. C. R. Soc. Biol. 154: 1396-1400 (1960).

- Plasma corticosterone concentration in foetal rat. Horm. Metab. Res. 5: 66 (1973).

Dupouy, J. P.: Differentiation of MSH-, ACTH-, endorphin-, and LPH-containing cells in the hypophysis during embryonic and fetal development. Int. Rev. Cytol. 68: 197-249 (1980).

Dupouy, J. P. and M. P. Dubois: Ontogenesis of the $\alpha$-MSH, $\beta$-MSH and ACTH cells in the foetal hypophysis of the rat. Correlation with the growth of the adrenals and adrenocortical activity. Cell Tiss. Res. 161: 373-384 (1975).

Dupouy, J. P., H. Coffigny and S. MAgRe: Maternal and foetal corticosterone levels during late pregnancy in rats. J. Endocrinol. 65: 347-352 (1975).

Hashimoto, S., G. Fumagalli, A. Zanini and J. MelDOLESI: Sorting of three secretory proteins to distinct secretory granules in acidophilic cells of cow anterior pituitary. J. Cell Biol. 105: 1579-1586 (1985).

Hemming, F. J., M. Begeot, M. P. Dubois and P. M. DuBoIs: Fetal rat somatotropes in vitro: effects of insulin, cortisol, and growth hormone-releasing factor on their differentiation: a light and electron microscopic study. Endocrinology 114: 2107-2113 (1984).

Hemming, F. J., M. L. Aubert and P. M. Dubois: Differentiation of fetal rat somatotropes in vitro: effects of cortisol, 3,5,3'-triiodothyronine, and glucagon, a light microscopic and radioimmunological study. Endocrinology 123: 1230-1236 (1988).

Jost, A.: Problems of fetal endocrinology: the adrenal glands. Rec. Prog. Hormone Res. 22: 541-574 (1966).

Kalavsky, S. M.: Fetal rat adrenal steroidogenesis. Biol. Neonate 17: 427-435 (1971).

Keeney, D. S., C. M. Jenkins and M. R. Waterman: Developmentally regulated expression of adrenal $17 \alpha$ hydroxylase cytochrome P450 in the mouse embryo. Endocrinology 136: 4872-4879 (1995).

KITCHELL, R. L.: Compensatory hypertrophy of the intact adrenal of fetal rats subjected to unilateral adrenalectomy. Proc. Soc. Exp. Biol. Med. 75: 824-827 (1950).

KitchelL, R. L. and L. J. Wells: Functioning of the hypophysis and adrenals in fetal rats: effects of hypophysectomy, adrenalectomy, castration, injected ACTH and implanted sex hormones. Anat. Rec. 112: 541-591 (1952).

Nagata, S., M. G. Rosenfeld and K. Inoue: Development of prolactin and growth hormone production in the fetal rat pituitary: an immunochemical study. Devel. Growth Differ. 34: 473-478 (1992). 
Nemeskéri, Â. and B. HaLÂsz: Cultured fetal rat pituitaries kept in synthetic medium are able to initiate synthesis of trophic hormones. Cell Tiss. Res. 255: 645650 (1989).

Nemeskéri, Á., G. SÉTÁló and B. HaLÂSz: Ontogenesis of the three parts of the fetal rat adenohypophysis. A detailed immunohistochemical analysis. Neuroendocrinology 48: 534-543 (1988).

Nikitovitch-Winer, M. B., J. A. Atkin and B. E. MALEY: Colocalization of prolactin and growth hormone within specific adenohypophyseal cells in male, female, and lactating female rats. Endocrinology 121: 625-630 (1987).

Nogami, H., K. Suzuki, H. Enomoto and H. Ishikawa: Studies on the development of growth hormone and prolactin cells in the rat pituitary gland by in situ hybridization. Cell Tiss. Res. 255: 23-28 (1989).

Nogami, H., T. Yokose and T. Tachibana: Regulation of growth hormone expression in fetal rat pituitary gland by thyroid or glucocorticoid hormone. Amer. J. Physiol. 268: E262-267 (1995).

Nogami, H., K. Inoue and K. Kawamura: Involvement of glucocorticoid-induced factor(s) in the stimulation of growth hormone expression in the fetal rat pituitary gland in vitro. Endocrinology 138: 1810-1815 (1997).

Porter, T. E., B. Hill, C. D. Wiles and L. S. Frawley: Is the mammo-somatotrope a transitional cell for the functional interconversion of growth hormone- and prolaction-secreting cells? Suggestive evidence from virgin, gestating, and lacting rats. Endocrinology 127: 2789-2794 (1990).

Porter, T. E., C. D. Wiles and L. S. Frawley: Evidence for bidirectional interconversion of mammotropes and somatotropes: rapid reversion of acidophilic cell types to progestational proportions after weaning. Endocrinology 129: 1215-1220 (1991).

SaSaki, F. and F. Iwama: Two types of mammosomatotropes in mouse adenohypophysis. Cell Tiss. Res. 256: 645-648 (1989).

SÉTÁLó, G. and P. K. NaKane: Functional differentiation of the fetal anterior pituitary cells in the rat. Endocrinol. Exp. 10:155-166 (1976).
Simmons, D. M., J. W. Voss, H. A. Ingraham, J. M. Holloway, R. S. BRoIde, M. G. Rosenfeld and L. W. Swanson: Pituitary cell phenotypes involve cellspecific Pit-1 mRNA translation and synergistic interactions with other classes of transcription factors. Genes Devel. 4: 695-711 (1990).

Subramaniam, N., W. Cairns and S. OKret: Studies on the mechanism of glucocorticoid-mediated repression from a negative glucocorticoid response element from the bovine prolactin gene. DNA Cell Biol. 16: 153-163 (1997).

Watanabe, Y. G.: Failure of luteinizing hormone-releasing hormone (LHRH) to affect the differentiation of $\mathrm{LH}$ cells in the rat hypophysial primordium in serum free culture. Cell Tiss. Res. 250: 35-42 (1987).

Watanabe, Y. G. and S. Daikoku: An immunohistochemical study on the cytogenesis of adenohypophysial cells in fetal rats. Devel. Biol. 68: 557-567 (1979).

Watanabe, Y. G. and H. Haraguchi: Immunohistochemical study of the cytogenesis of prolactin and growth hormone cells in the anterior pituitary gland of the fetal rat. Arch. Histol. Cytol. 57: 161-166 (1994).

Prof. Yuichi G. WATANABE Department of Biology Faculty of Science Niigata University Igarashi-2, Niigata 950-2102 Japan

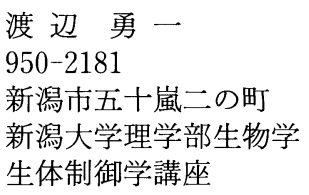

